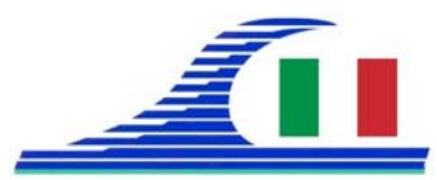

Conférence Méditerranéenne Côtière et Maritime EDITION 3, FERRARA, ITALIA (2015)

Coastal and Maritime Mediterranean Conference

Disponible en ligne - http://www.paralia.fr - Available online

\title{
Monitoring turbidity and sediment re-suspension induced by channel dredging and subaqueous disposal in a deficit lagoon
}

\section{Annelore BEZZI ${ }^{1}$, Raffaella PIANI ${ }^{1}$, Simone PILLON ${ }^{1}$, Marco LIPIZER ${ }^{2}$, Antonio BRATUS ${ }^{2}$, Giorgio FONTOLAN ${ }^{1}$}

\author{
1. Università degli Studi di Trieste Dipartimento di Matematica e Geoscienze, \\ via Weiss 1, 34128 Trieste, Italy. \\ bezzi@units.it
}

2. Regione Autonoma Friuli Venezia Giulia Direzione Ambiente ed Energia, via Giulia 75/1, 34126 Trieste, Italy.

marco.lipizer@regione.fvg.it

\begin{abstract}
:
In order to test a procedure for sustainable management of sediment in Marano and Grado Lagoon, consisting of dredging the Coron channel and sediment disposal in a deeper part of the same channel, an impact assessment of turbidity and sediment resuspension has been carried out, by means of Acoustic Doppler Current Profiler surveys, suspended particulate matter collection and placement of sediment traps.

Dredging and disposal operations cause an alteration of water turbidity, generating plumes that are driven by tidal currents within the channel and persist in water column for hours. Tidal flats next to the channel are involved in an anomalous sedimentation rate, temporally and spatially restricted. Background concentration during dredging and disposal operations is consistent with those caused by the wind waves. Peak values of concentration in channel and maximum rates of sedimentation on tidal flat are consistent with those caused by clam fishing with mechanical dredges, permitted on the same areas. Results indicate the possibility to adopt this type of sediment management practice as a good low-impact provisional procedure in this part of the lagoon.
\end{abstract}

Keywords: Sediment management, Dredging, Lagoon, Suspended particulate matter.

\section{Introduction}

The Marano and Grado Lagoon is the easternmost part of a microtidal lagoon system in the North Adriatic, including habitats of extreme ecological meaning and different human activities (dredging of channels for navigation, clam culture), whereas sea level rise and scarce sediment supply characterized it. Therefore, the prevention of waterways siltation needs a plan for a sustainable management of sediment.

In June 2013 the Coron channel was dredged and the dredged sediment was dumped in the deepest part of the same channel (Figure 1). The site is located in Lignano basin, which is characterized by a tidal prism of $40 \times 10^{6} \mathrm{~m}^{3}$ and tidal current velocity, decreasing from the Lignano inlet (up to $1 \mathrm{~m} / \mathrm{s})$ to the inner part $(0.25-0.03 \mathrm{~m} / \mathrm{s}$ ) 
Côtes méditerranéennes menacées :

Risques et défis dans le contexte du changement climatique

(DORIGO, 1965). The dredged area was $2750 \mathrm{~m}$ long and $10 \mathrm{~m}$ wide for a volume of $33000 \mathrm{~m}^{3}$ of silty sediment; the disposal area was $7 \mathrm{~m}$ deep, $500 \mathrm{~m}$ long and $80 \mathrm{~m}$ wide. In agreement with the local authority Regione Friuli Venezia Giulia, an impact assessment of turbidity and sediment re-suspension was conducted on both areas. The aim was to test a low impact procedure, allowing to hold the sediment inside the lagoon, waiting for new regulations which would allow the reconstruction of saltmarshes using dredged sediments.

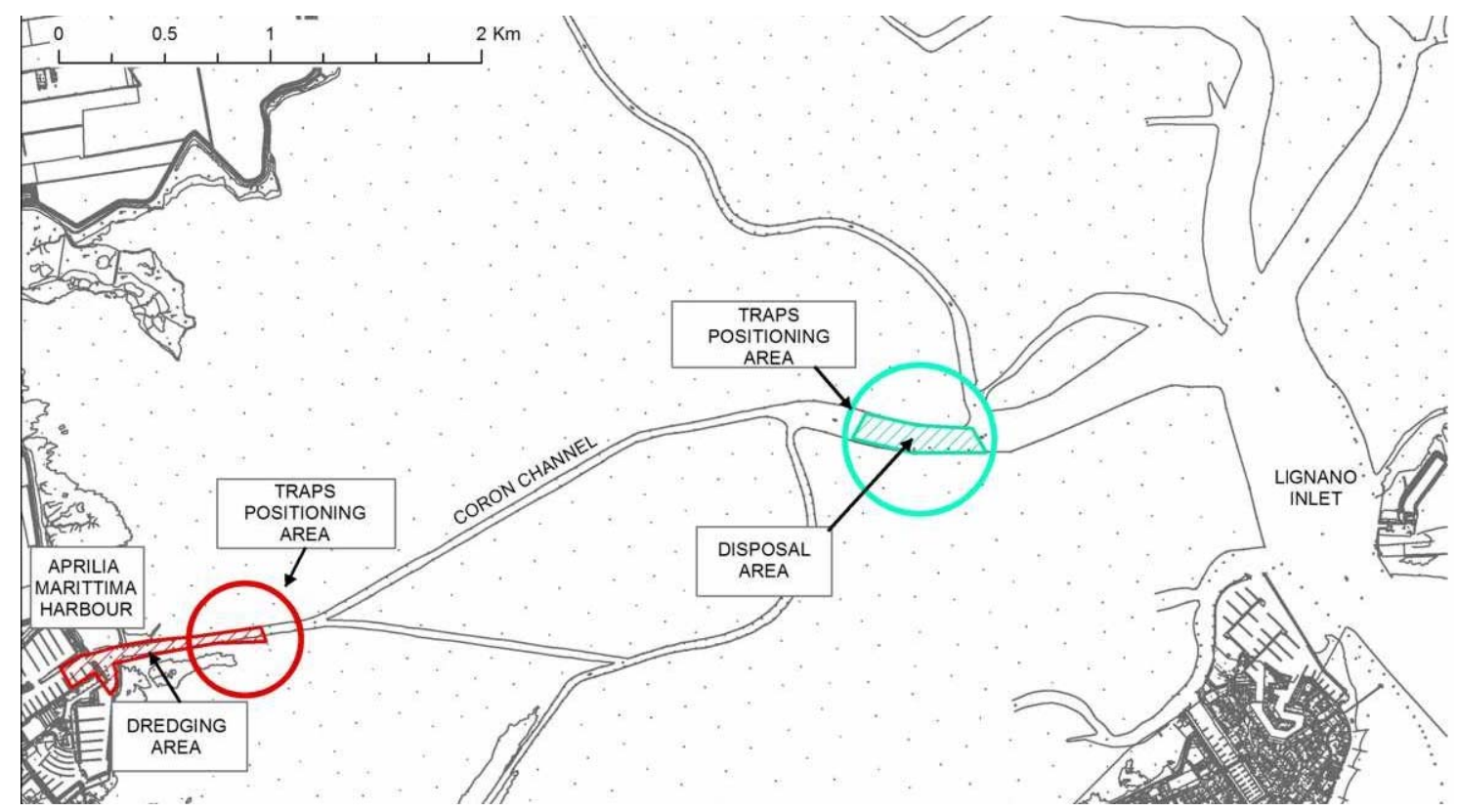

Figure 1. Study area, with location of areas of intervention.

\section{Materials and methods}

Daily surveys during dredging and disposal operations (5 days, named progressively from 1 to 5) and without operations (1 day, named day 6), with different tidal conditions, were carried out. Near $19 \mathrm{~km}$ of zig-zag lines along the channel were surveyed by a vessel-mounted Acoustic Doppler Current Profiler (ADCP) collecting data of backscatter, current direction and velocity (v) along water column. 24 samples of suspended particulate matter (SPM) were collected by Niskin bottle and 64 sediment traps were placed on tidal flats in order to measure vertical sedimentation.

SPM concentrations were obtained by filtration of water samples on cellulose filters and determination of weight after drying at $55^{\circ} \mathrm{C}$. ADCP backscatter data were calibrated to SPM discrete samples. Sediment collected by traps were weighted and analyzed by Granulometer Malvern Laser Mastersizer 2000. 
Mediterranean coasts at threat:

Hazards and challenges in the context of climate variability

\section{Results}

Dredging operations caused plumes of suspended sediment driven by tidal currents within the channel. On flood tide $(\mathrm{v}=0.25 \mathrm{~m} / \mathrm{s})$ an alteration of the turbidity (SPM peaks up to $1600 \mathrm{mg} / \mathrm{l}$ ) was measured immediately downdrift from dredge (Figure 2); turbidity decreased with the distance $(300 \mathrm{~m}$ ) up to reach constant SPM values (40-60 $\mathrm{mg} / \mathrm{l}$ ) and within 4 hours to values lower than $20 \mathrm{mg} / \mathrm{l}$ (background).

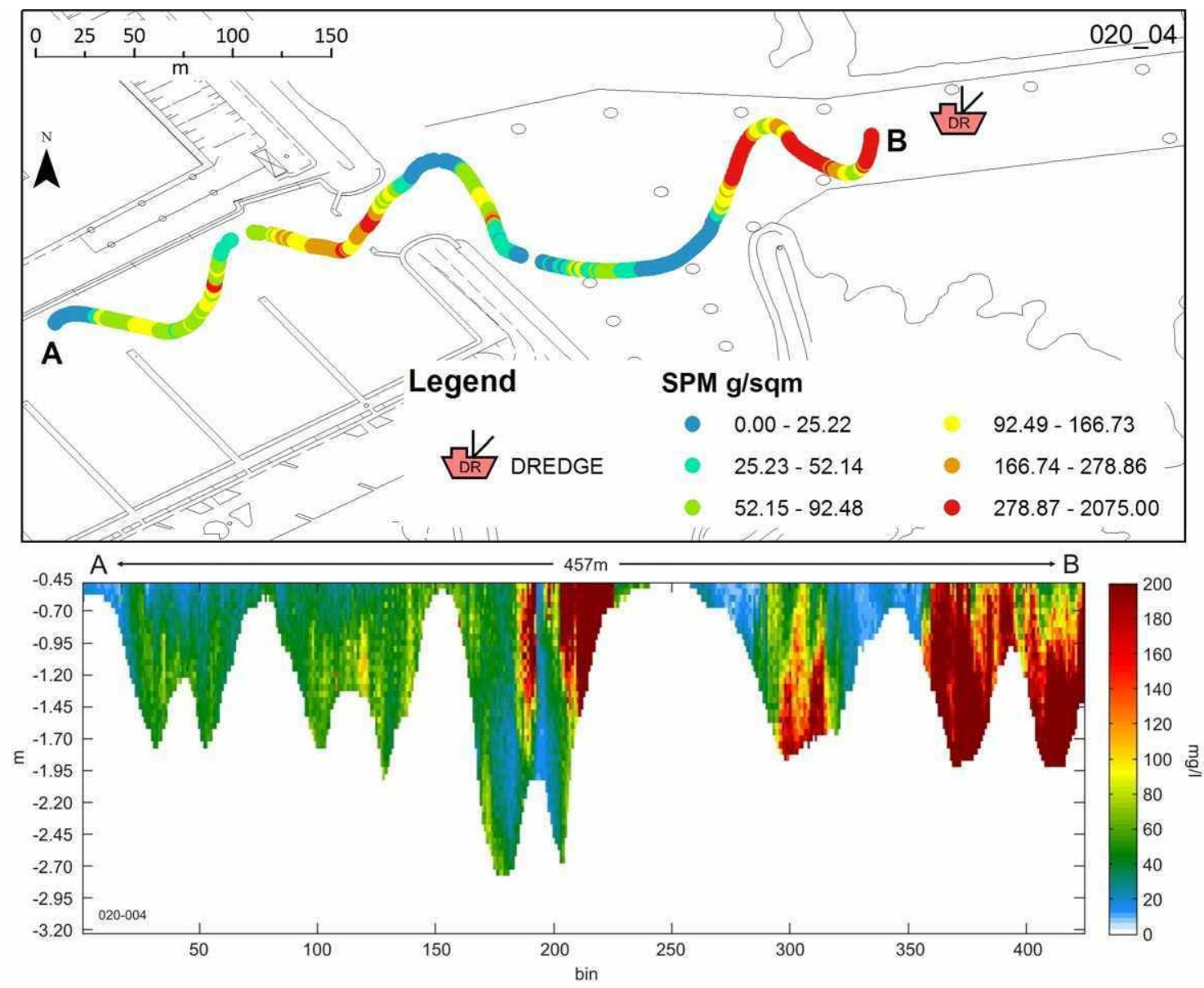

Figure 2. ADCP transect 020_04 in the dredging area during flood tide (drift from rights to left) on day 3 of survey (June 11, 2013).

In the opposite side of the channel, updrift from the dredge, water showed concentration between 5 and $10 \mathrm{mg} / \mathrm{l}$, according to values measured in the lagoon without wind (BELLI et al., 1996).

Disposal operations caused peaks of turbidity, driven by tidal currents. During ebb tide $(\mathrm{v}=0.35-0.40 \mathrm{~m} / \mathrm{s})$ estimated concentrations were very high $(1200 \mathrm{mg} / \mathrm{l}$ measured at 60 $\mathrm{m}$ from the dredge) and decayed to the background values of $20 \mathrm{mg} / \mathrm{l}$ at a distance beyond $300 \mathrm{~m}$. During flood tide the suspended sediment was driven along the channel 
Côtes méditerranéennes menacées :

Risques et défis dans le contexte du changement climatique

toward the Lignano inlet and the peak concentrations (up to $1400 \mathrm{mg} / \mathrm{l}$ ) decayed within $200 \mathrm{~m}$ to background values. Mean size of SPM ranged from 6.2 to 7.2 phi.

Fluxes of sediments driven toward the tidal flats and collected by traps varied between 0.05 and $26.42 \mathrm{~g} / \mathrm{m}^{2} \mathrm{~h}$. On days $1,2,5$, amounts were lower than those of day 6 (without operations). Quantities collected during these days are consistent with, or lower than, natural fluxes estimated between 0.68 and $20.68 \mathrm{~g} / \mathrm{m}^{2} \mathrm{~h}$ according to local weather condition (BURLA \& FONTOLAN, 2003). Higher amounts were observed in dredging area only at ebb tide on day 3 , in the disposal area during slack on day 3 , and during flood tide on day 4.

\section{Conclusions}

Dredging and disposal operations cause alteration of water turbidity, generating plumes that are driven by tidal currents within the channel and persist in the water column for hours. With northeasterly and southwesterly winds sediment re-suspension is consistent with background turbidity measured during dredging operations, but it persists longer (days versus hours) in lagoon waters.

Tidal flats nearby the channel are involved in an anomalous sedimentation rate, temporally and spatially restricted, only with favorable tide conditions and within $100 \mathrm{~m}$ from the channel. The alteration is greater in the dredging area.

Peak values of concentration in the channel and maximum sediment flux on the tidal flat are consistent with those caused by clam fishing with mechanical dredges (BURLA \& FONTOLAN, 2003), which have been given the permission to operate in the same areas.

Results indicate the possibility to adopt this type of dredging - disposal procedure as a good low impact provisional procedure in this part of the lagoon.

\section{References}

BELLI M., COLIZZA E., FANZUTTI G.P., FINOCCHIARO F., MAROCCO R., MELIS R., PIANI R., SANSONE U. (1996). Stato delle conoscenze e programmi futuri sulle indagini sedimentologiche e radioecologiche nella Laguna di Marano e Grado. 10 Anni da Cernobyl: ricerche in radioecologia, monitoraggio ambientale e radioprotezione, Trieste, Atti ANPA, pp 151-157.

BURLA I., FONTOLAN G. (2003). The impact of clam fishing dredges on Adriatic lagoons. Proc. VI International Conference on the Mediterranean Coastal Environment, MEDCOAST 03, Ravenna, Italy, Vol. 2, pp 1269-1280.

DORIGO L. (1965). La Laguna di Grado e le sue foci. Grafiche Gasparoni, Venezia, $231 \mathrm{p}$. 